\title{
CORRECTIONS
}

\section{Diabetes control in older people}

In the second paragraph of this Editorial we incorrectly attributed the second sentence to "previous American Geriatrics Society guidelines" as the result of an error introduced during the editing process (BMJ 2013;346:f2625, doi:10.1136/bmj. f2625). In fact, the recommendation that treatment should aim to achieve "a glycated haemoglobin $\left(\mathrm{HbA}_{1 \mathrm{c}}\right)$ of less than 53 $\mathrm{mmol} / \mathrm{mol}(<7 \%)$ for all adults, regardless of age" was issued by the American Diabetes Association, in a consensus statement with the European Association for the Study of Diabetes, which is fully cited in reference 2 . However, the link provided for reference 2 is incorrect and should have linked here http://care. diabetesjournals.org/content/29/8/1963.full.

Cite this as: BMJ 2013;346:f2836

๑ BMJ Publishing Group Ltd 2013 